\title{
Soft tissue masses: distribution of entities and rate of malignancy in small lesions
}

Felix G. Gassert ${ }^{1 *}$ D, Florian T. Gassert ${ }^{1}$, Katja Specht ${ }^{2}$, Carolin Knebel ${ }^{3}$, Ulrich Lenze ${ }^{3}$, Marcus R. Makowski ${ }^{1}$, Rüdiger von Eisenhart-Rothe ${ }^{3}$, Alexandra S. Gersing ${ }^{1}$ and Klaus Woertler ${ }^{1}$

\begin{abstract}
Background: Small soft tissue masses are often falsely assumed to be benign and resected with failure to achieve tumor-free margins. Therefore, this study retrospectively investigated the distribution of histopathologic diagnosis to be encountered in small soft tissue tumors $(\leq 5 \mathrm{~cm})$ in a large series of a tertiary referral center.

Methods: Patients with a soft tissue mass (STM) with a maximum diameter of $5 \mathrm{~cm}$ presenting at our institution over a period of 10 years, who had undergone preoperative Magnetic resonance imaging and consequent biopsy or/and surgical resection, were included in this study. A final histopathological diagnosis was available in all cases. The maximum tumor diameter was determined on MR images by one radiologist. Moreover, tumor localization (head/neck, trunk, upper extremity, lower extremity, hand, foot) and depth (superficial / deep to fascia) were assessed.
\end{abstract}

Results: In total, histopathologic results and MR images of 1753 patients were reviewed. Eight hundred seventy patients (49.63\%) showed a STM $\leq 5 \mathrm{~cm}$ and were therefore included in this study (46.79 +/- 18.08 years, 464 women). Mean maximum diameter of the assessed STMs was $2.88 \mathrm{~cm}$. Of 870 analyzed lesions $\leq 5 \mathrm{~cm}, 170(19.54 \%)$ were classified as superficial and $700(80.46 \%)$ as deep. The malignancy rate of all lesions $\leq 5 \mathrm{~cm}$ was at $22.41 \%$ (superficial: $23.53 \%$ / deep: $22.14 \%)$. The malignancy rate dropped to $16.49 \%$ (20.79\% / 15.32\%) when assessing lesions $\leq 3 \mathrm{~cm}(p=0.007)$ and to $15.0 \%(18.18 \% / 13.79 \%)$ when assessing lesions $\leq 2 \mathrm{~cm}(p=0.006)$.

Overall, lipoma was the most common benign lesion of superficial STMs (29.41\%) and tenosynovial giant cell tumor was the most common benign lesion of deep STMs (23.29\%). Undifferentiated pleomorphic sarcoma was the most common malignant diagnosis among both, superficial (5.29\%) and deep (3.57\%) STMs.

Conclusions: The rate of malignancy decreased significantly with tumor size in both, superficial and deep STMs. The distribution of entities was different between superficial and deep STMs, yet there was no significant difference found in the malignancy rate.

\footnotetext{
* Correspondence: felix.gassert@tum.de

${ }^{1}$ Department of Diagnostic and Interventional Radiology, School of Medicine \& Klinikum rechts der Isar, Technical University of Munich, Ismaninger Str. 22, 81675 Munich, Germany

Full list of author information is available at the end of the article
}

(C) The Author(s). 2021 Open Access This article is licensed under a Creative Commons Attribution 4.0 International License, which permits use, sharing, adaptation, distribution and reproduction in any medium or format, as long as you give appropriate credit to the original author(s) and the source, provide a link to the Creative Commons licence, and indicate if changes were made. The images or other third party material in this article are included in the article's Creative Commons licence, unless indicated otherwise in a credit line to the material. If material is not included in the article's Creative Commons licence and your intended use is not permitted by statutory regulation or exceeds the permitted use, you will need to obtain permission directly from the copyright holder. To view a copy of this licence, visit http://creativecommons.org/licenses/by/4.0/. The Creative Commons Public Domain Dedication waiver (http://creativecommons.org/publicdomain/zero/1.0/) applies to the data made available in this article, unless otherwise stated in a credit line to the data. 


\section{Background}

Malignant soft tissue tumors account for approximately $1 \%$ of all adult and approximately $20 \%$ of all pediatric solid malignant cancers $[1,2]$. The most common entities among malignant soft tissue sarcomas are liposarcoma, leiomyosarcoma, and undifferentiated pleomorphic sarcoma [3]. In the 5th edition of the classification of soft tissue tumors, the World Health Organisation (WHO) defined several categories of soft tissue lesions with further subcategories and indicated their dignity with either benign, intermediate (locally aggressive or rarely metastasizing) or malignant [4].

The T1 stage of malignant tumors is defined by the American Joint Committee on Cancer (AJCC) as a lesion with a diameter $<5 \mathrm{~cm}$ [5]. Although malignant lesions are usually larger in size, small soft tissue masses (STMs) still comprise a considerable proportion of malignant soft tissue tumors [6]. Datir et al. showed that approximately $10 \%$ of malignant STMs were staged as T1 tumors at initial diagnosis, which correlates with a maximum tumor size of $5 \mathrm{~cm}$ [7].

In clinical practice, smaller lesions are often assumed to be benign and therefore, commonly undergo inadequate resection outside specialized tumor centers. Furthermore, current guidelines include resection-biopsy for soft tissue lesions with a diameter of less than $3 \mathrm{~cm}$, possibly leading to an excision of malignant tumors with failure to achieve tumor-free margins $[8,9]$. It is therefore highly relevant to know the precise percentage of malignancies in small soft tissue lesions and to be able to estimate the distribution of expected entities even without having performed advanced imaging.

A study published by Pham et al. showed a malignancy rate of $21 \%$ of soft tissue tumors smaller than $2 \mathrm{~cm}$, excluding simple lipomas, juxta-articular cysts, metastases, and soft tissue

lesions without histological confirmation [10]. Nevertheless, the sample size of their series was small $(n=$ 42), and no further differentiation according to tumor sizes was performed. To our knowledge, there was no recent study performed that evaluated the distribution of STMs in a larger study cohort.

To improve differentiation between benign and malignant STMs on Magnetic resonance (MR) imaging, Obaid et al. created a risk stratification model including criteria, such as edema, intralesional fat and signal intensity patterns as well as lesion size in a series of 110 patients [11]. Although average malignant lesions showed a larger diameter, approximately $15 \%$ of lesions with a diameter of less than $5 \mathrm{~cm}$ were malignant in their study. Consequently, especially in small lesions a more precise evaluation of the distribution of tumor entity and rate of malignancy, depending on the maximum diameter, could help to determine further diagnostic workup and treatment.
Therefore, in this study we aimed to determine the rate of malignancy depending on tumor size and assessed the distribution of the entities of soft tissue tumors with a maximum diameter of less than $5 \mathrm{~cm}, 3 \mathrm{~cm}$ and $2 \mathrm{~cm}$.

\section{Methods \\ Subjects}

Approval of the Institutional Review Board was obtained prior to this study. Written informed consent was waived for this retrospective analysis of routinely acquired imaging and clinical data. Over a period of 10 years (January 2010 through March 2020) all patients with a STM presenting at our tertiary care center, who received biopsy or / and surgical resection with a final histopathological diagnosis, were selected from our musculoskeletal database for further analysis $(n=2172)$.

\section{Image acquisition and diameter evaluation}

Imaging of the soft tissue mass was performed on either a 1.5 or a 3 Tesla MR scanner in all subjects prior to surgery using various protocols. All MR protocols included sequences in both, the short and the long axis allowing for proper evaluation of tumor diameter and location with respect to the deep fascia. Patients without available preoperative MR images were excluded from this study $(n=374)$. In the remaining 1978 patients, the precise maximum tumor diameter was determined on MR images by one radiologist (F.G.G.). All available cases with a maximum diameter of $5 \mathrm{~cm}$ and smaller were included in this study $(n=870)$. Besides histopathological diagnosis of the STMs, tumor location was extracted from the database including the categories "Head/Neck", "Trunk", "Upper Extremity" (without hand), "Lower Extremity" (without foot), "Hand" and "Foot". Additionally, analysis of tumor depth in relation to the fascia (superficial / deep to fascia) and differentiation between patients younger than 18 years (age group A), patients between 18 and 40 years (age group B) and patients older than 40 years (age group C) was performed and included in this study. For evaluation of intra-reader reproducibility, the tumor diameter of 20 lesions was reevaluated after 14 days.

\section{Assessment of STMs}

A final histopathological diagnosis was available in all of these selected cases. Classification of lesions was adjusted to the 5th edition of classification of tumors of soft tissue and bone of the WHO according to the final histologic diagnosis [4]. Lesions in the intermediate category capable of local recurrence but not capable of distant metastasis were considered as benign for this analysis. Low-grade liposarcomas/atypical lipomatous tumors were excepted from this proceeding and 
summarized under the diagnosis "liposarcoma". A separate analysis of low- and high-grade liposarcomas was however performed as well.

Some lesions represented in our database were identified as sarcomas, but further histological specification was not possible / performed at the time of diagnosis. These lesions were assigned to the category "Sarcoma not otherwise specified". Differentiation between malignant and benign lesions was also performed according to the WHO classification. In total, 21 malignant and 16 benign histopathological entities were used for this analysis. Additionally, further histopathological specification of non-neoplastic masses was performed.

\section{Statistical analyses}

All statistical analyses were performed using $\mathrm{R}$ version 3.2.4 (R Foundation for Statistical Computing). Method of least squares was applied for Regression analyses of malignancy rate as a function of diameter. Chi-square test was performed in order to analyse the differences in malignancy rates and Wilcoxon rank-sum in order to analyse the differences in patient age between the $\leq 5$ $\mathrm{cm}$ and the $\leq 3 \mathrm{~cm} / \leq 2 \mathrm{~cm}$ group. For all analysis, a $p$ value of $\leq 0.05$ was considered significant. For the evaluation of the intra-reader reproducibility, determination of the maximum diameter was repeated after 14 days and Cohen's Kappa was calculated.

\section{Results}

\section{Demographics}

Of the 870 patients with a lesion $\leq 5 \mathrm{~cm}$ included in our study, 406 (46.67\%) were male and 464 (53.33\%) were female with a mean age of $46.79+/-18.08$ years. 46 (5.29\%) of the patients were under the age of 18 years, 289 (33.22\%) between 18 and 40 years and 535 (61.49\%) older than 40 years. Among the 473 patients with lesions $\leq 3 \mathrm{~cm}, 277$ (58.56\%) were female and the mean age was $46.04+/-16.9$ years, and among the 240 patients with lesions $\leq 2 \mathrm{~cm}, 143(59.58 \%)$ were female and the mean age was $44.87+/-16.72$ years. No significant differences were observed comparing distribution of gender for STMs $\leq 5 \mathrm{~cm}$ vs. STMs $\leq 3 \mathrm{~cm}(P=0.08)$ and for STMs $\leq 5 \mathrm{~cm}$ vs. STMs $\leq 2 \mathrm{~cm}(P=0.09)$ as well as age $(P=$ 0.56 and $P=0.16$, respectively) between the three groups.

\section{Distribution of tumor entities depending on size, depth, location and patient age}

The mean maximum tumor diameter across all STMs $\leq 5 \mathrm{~cm}$ was $2.88 \mathrm{~cm}$ (STMs $\leq 3 \mathrm{~cm}: 1.99 \mathrm{~cm}$; STMs $\leq 2 \mathrm{~cm}$ : $1.46 \mathrm{~cm}$ ). Reevaluation of maximum tumor diameter of 20 lesions after 14 days showed an excellent intra-reader reproducibility ( $\kappa=0.883$ ). Distribution of tumor entities was analyzed for the STMs $\leq 5 \mathrm{~cm}, \leq 3 \mathrm{~cm}$ and $\leq 2 \mathrm{~cm}$ and sorted into benign, malignant and non-neoplastic masses. Results are shown in Table 1. Tenosynovial giant cell tumor was the most common diagnosis among the benign STMs $(19.43 \%$ of all STMs $\leq 5 \mathrm{~cm})$ whereas undifferentiated pleomorphic sarcoma was most common among the malignant STMs (3.91\% of all STMs $\leq 5 \mathrm{~cm}$ ), independent of the measured maximum tumor diameter. Among the non-neoplastic soft tissue masses, ganglion was the most common diagnosis ( $7.47 \%$ of all STMs $\leq 5 \mathrm{~cm}$ ).

Regarding the localization of the analyzed STMs, 170 lesions (19.54\%) were classified as superficial and 700 as deep (80.46\%). The distributions of entities among superficial and deep lesions are shown in Tables 2 and 3. Overall, lipoma was the most common benign lesion of the superficially located STMs (29.41\%) and tenosynovial giant cell tumor was the most common benign lesion of the deeply located STMs (23.39\%). Undifferentiated pleomorphic sarcoma was the most common malignant diagnosis among both, superficial (5.29\%) and deep STMs (3.57\%).

Furthermore, of the 870 STMs $\leq 5 \mathrm{~cm}, 35(4.02 \%)$ were located at the head and neck region, $70(8.05 \%)$ at the trunk, $186(21.38 \%)$ at the upper and $401(46.09 \%)$ at the lower extremity, $57(6.55 \%)$ at the hand, and 121 (13.91\%) at the foot.

Synovial sarcoma $(8.69 \%)$ and alveolar soft part sarcoma (6.52\%) were the most common tumors in age group A, synovial sarcoma (2.42\%), myxofibrosarcoma and dermatofibrosarcoma (both 2.08\%) in age group B, and undifferentiated pleomorphic sarcoma (6\%) and liposarcoma $(4.67 \%)$ in age group C.

The most common benign tumors in age groups $\mathrm{A}$ and B were tenosynovial giant cell tumor $(19.56 \%$ / $28.37 \%)$ and hemangioma (15.21\% / 13.84\%), whereas tenosynovial giant cell tumor (14.58\%) and lipoma $(13.46 \%)$ were the most common benign lesions in age group C.

\section{Malignancy rates}

Overall, the malignancy rate (malignant vs benign + non-neoplastic masses) was at $22.41 \%$ for STMs $\leq 5 \mathrm{~cm}$. The malignancy rate dropped significantly to $16.49 \%$ when assessing lesions $\leq 3 \mathrm{~cm}(P=0.007)$ and to $15.0 \%$ when assessing lesions $\leq 2 \mathrm{~cm}(P=0.006)$. The regression analysis for the malignancy rate as a function of maximum diameter is shown in Fig. 1. The malignancy rate of superficial STMs was at 23.53\% (STMs $\leq 3 \mathrm{~cm}$ : $19.19 \%$ / STMs $\leq 2 \mathrm{~cm}: 18.46 \%)$ and of deep STMs at $22.14 \%$ (15.32\% / 13.79\%), with no significant difference between the three groups $(P=0.97 / P=0.49 / P=$ 0.95). Nevertheless, the malignancy rate for STMs $\leq 5$ $\mathrm{cm}$ varied depending on tumor localization as shown in Table 4 $(P<0.001)$. The foot region showed the lowest and the head and neck region the highest malignancy 


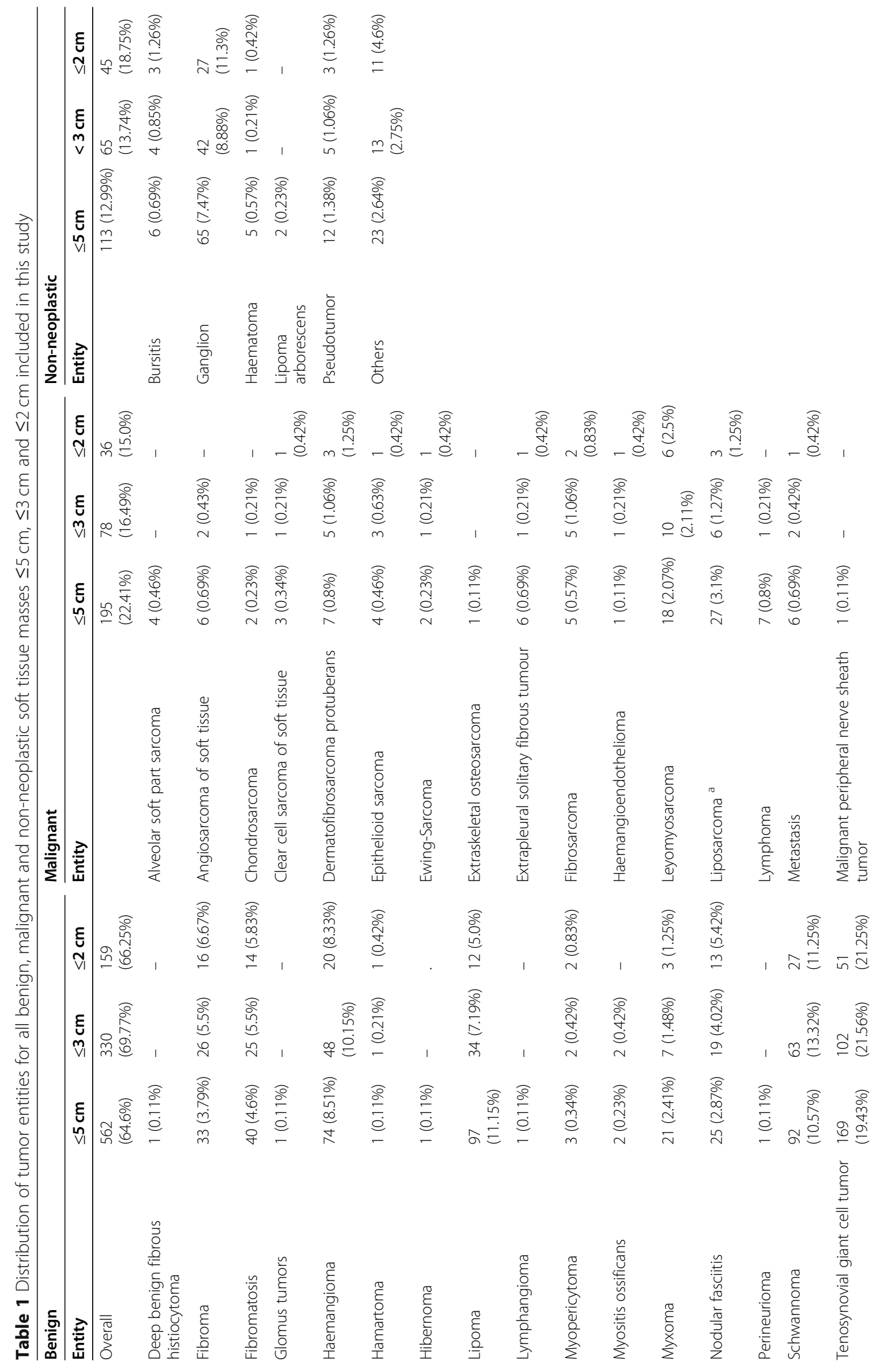




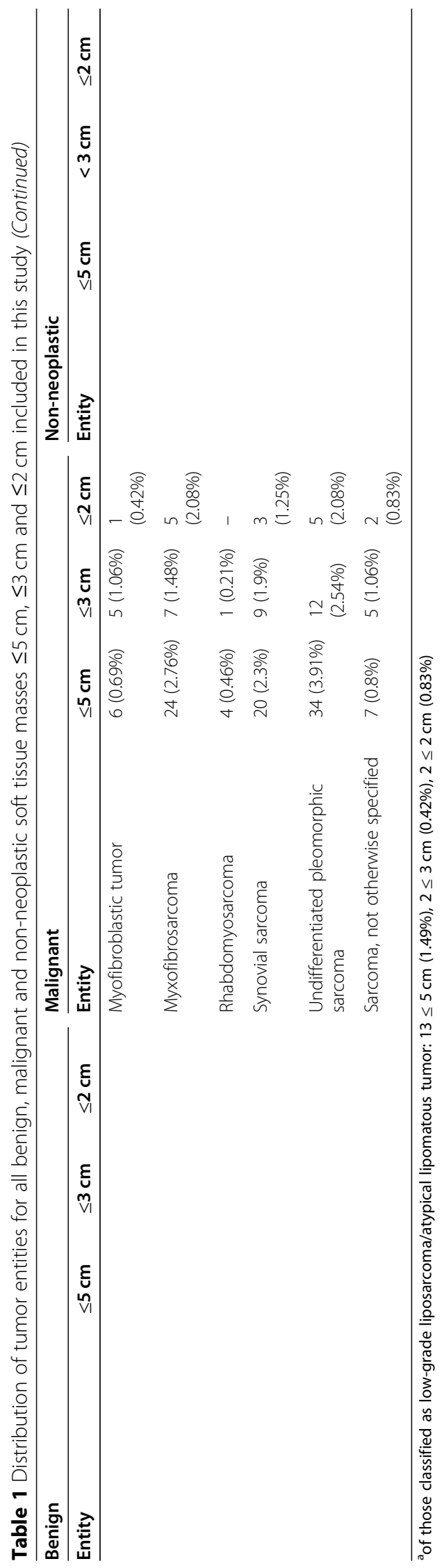




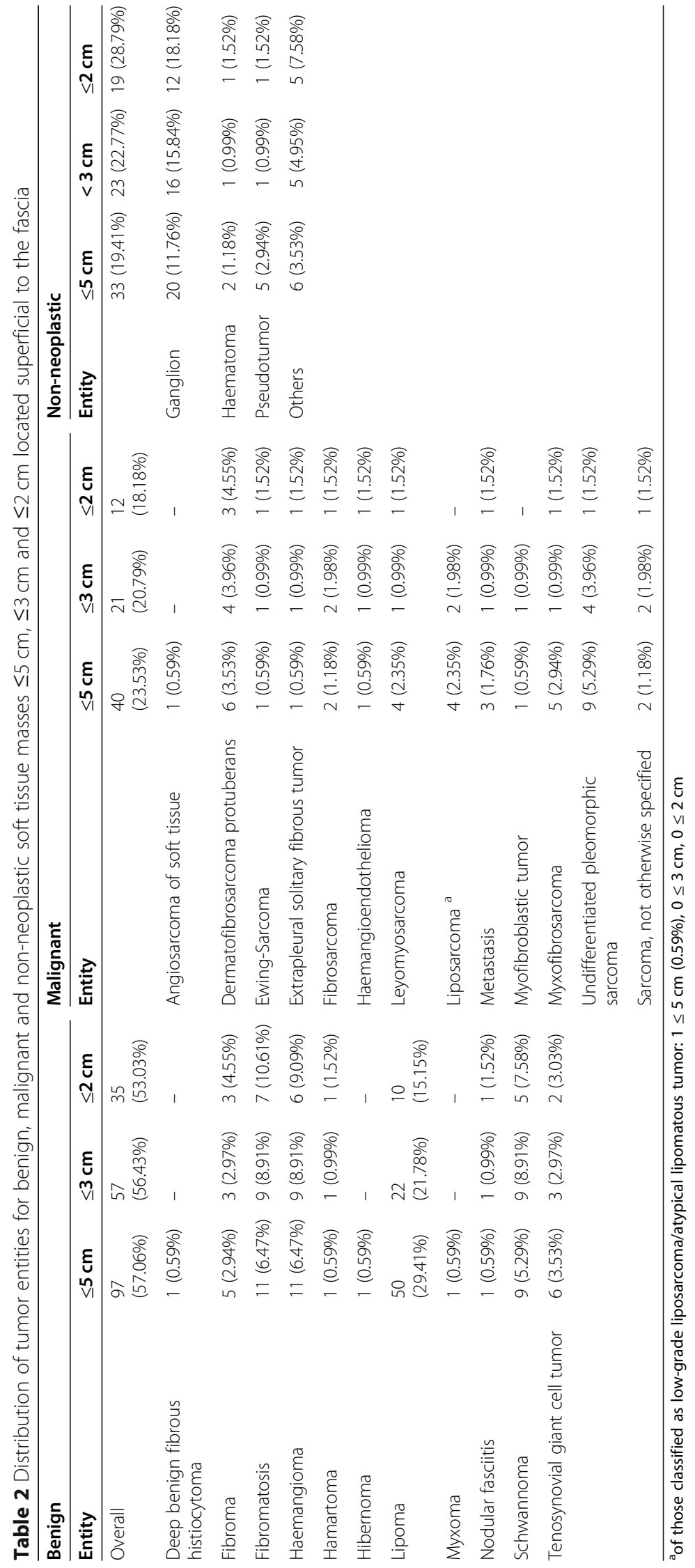


Table 3 Distribution of tumor entities for benign, malignant and non-neoplastic soft tissue masses $\leq 5 \mathrm{~cm}, \leq 3 \mathrm{~cm}$ and $\leq 2 \mathrm{~cm}$ located deep to the fascia

\begin{tabular}{|c|c|c|c|c|c|c|c|c|c|c|c|}
\hline \multicolumn{4}{|l|}{ Benign } & \multicolumn{4}{|l|}{ Malignant } & \multicolumn{4}{|c|}{ Non-neoplastic } \\
\hline Entity & $\leq 5 \mathrm{~cm}$ & $\leq 3 \mathrm{~cm}$ & $\leq 2 \mathrm{~cm}$ & Entity & $\leq 5 \mathrm{~cm}$ & $\leq 3 \mathrm{~cm}$ & $\leq 2 \mathrm{~cm}$ & Entity & $\leq 5 \mathrm{~cm}$ & $<3 \mathrm{~cm}$ & $\leq 2 \mathrm{~cm}$ \\
\hline Overall & $\begin{array}{l}465 \\
(66.43 \%)\end{array}$ & $\begin{array}{l}273 \\
(73.39 \%)\end{array}$ & $\begin{array}{l}124 \\
(71.26 \%)\end{array}$ & & $\begin{array}{l}155 \\
(22.14 \%)\end{array}$ & $\begin{array}{l}57 \\
(15.32 \%)\end{array}$ & $\begin{array}{l}24 \\
(13.79 \%)\end{array}$ & & 80 (11.43\%) & $\begin{array}{l}42 \\
(11.29 \%)\end{array}$ & $\begin{array}{l}26 \\
(14.94 \%)\end{array}$ \\
\hline Fibroma & $\begin{array}{l}28 \\
(4.0 \%)\end{array}$ & $\begin{array}{l}23 \\
(6.18 \%)\end{array}$ & $\begin{array}{l}13 \\
(7.47 \%)\end{array}$ & $\begin{array}{l}\text { Alveolar soft part } \\
\text { sarcoma }\end{array}$ & $\begin{array}{l}4 \\
(0.57 \%)\end{array}$ & - & - & Bursitis & $6(0.86 \%)$ & $\begin{array}{l}4 \\
(1.08 \%)\end{array}$ & $\begin{array}{l}3 \\
(1.72 \%)\end{array}$ \\
\hline Fibromatosis & $\begin{array}{l}29 \\
(4.14 \%)\end{array}$ & $\begin{array}{l}17 \\
(4.57 \%)\end{array}$ & $\begin{array}{l}7 \\
(4.02 \%)\end{array}$ & $\begin{array}{l}\text { Angiosarcoma of soft } \\
\text { tissue }\end{array}$ & $\begin{array}{l}5 \\
(0.71 \%)\end{array}$ & $\begin{array}{l}2 \\
(0.54 \%)\end{array}$ & - & Ganglion & $45(6.43 \%)$ & $\begin{array}{l}26 \\
(6.99 \%)\end{array}$ & $\begin{array}{l}15 \\
(8.62 \%)\end{array}$ \\
\hline Glomus tumors & $\begin{array}{l}1 \\
(0.14 \%)\end{array}$ & - & - & Chondrosarcoma & $\begin{array}{l}2 \\
(0.29 \%)\end{array}$ & $\begin{array}{l}1 \\
(0.27 \%)\end{array}$ & - & Haematoma & $3(0.43 \%)$ & - & - \\
\hline Haemangioma & $\begin{array}{l}63 \\
(9.0 \%)\end{array}$ & $\begin{array}{l}39 \\
(10.48 \%)\end{array}$ & $\begin{array}{l}14 \\
(8.05 \%)\end{array}$ & $\begin{array}{l}\text { Clear cell sarcoma of } \\
\text { soft tissue }\end{array}$ & $\begin{array}{l}3 \\
(0.43 \%)\end{array}$ & $\begin{array}{l}1 \\
(0.27 \%)\end{array}$ & $\begin{array}{l}1 \\
(0.57 \%)\end{array}$ & $\begin{array}{l}\text { Lipoma } \\
\text { arborescens }\end{array}$ & $2(0.29 \%)$ & - & - \\
\hline Lipoma & $\begin{array}{l}47 \\
(6.71 \%)\end{array}$ & $\begin{array}{l}12 \\
(3.23 \%)\end{array}$ & $\begin{array}{l}2 \\
(1.15 \%)\end{array}$ & $\begin{array}{l}\text { Dermatofibrosarcoma } \\
\text { protuberans }\end{array}$ & $\begin{array}{l}1 \\
(0.14 \%)\end{array}$ & $\begin{array}{l}1 \\
(0.27 \%)\end{array}$ & - & Pseudotumor & $7(1.0 \%)$ & $\begin{array}{l}4 \\
(1.08 \%)\end{array}$ & $\begin{array}{l}2 \\
(1.15 \%)\end{array}$ \\
\hline Lymphangioma & $\begin{array}{l}1 \\
(0.14 \%)\end{array}$ & - & - & Epithelioid sarcoma & $\begin{array}{l}4 \\
(0.57 \%)\end{array}$ & $\begin{array}{l}3 \\
(0.81 \%)\end{array}$ & $\begin{array}{l}1 \\
(0.57 \%)\end{array}$ & Others & $17(2.43 \%)$ & $\begin{array}{l}8 \\
(2.15 \%)\end{array}$ & $\begin{array}{l}6 \\
(3.45 \%)\end{array}$ \\
\hline Myopericytoma & $\begin{array}{l}3 \\
(0.43 \%)\end{array}$ & $\begin{array}{l}2 \\
(0.54 \%)\end{array}$ & $\begin{array}{l}2 \\
(1.15 \%)\end{array}$ & Ewing-Sarcoma & $\begin{array}{l}1 \\
(0.14 \%)\end{array}$ & - & - & & & & \\
\hline $\begin{array}{l}\text { Myositis } \\
\text { ossificans }\end{array}$ & $\begin{array}{l}2 \\
(0.29 \%)\end{array}$ & $\begin{array}{l}2 \\
(0.54 \%)\end{array}$ & - & $\begin{array}{l}\text { Extraskeletal } \\
\text { osteosarcoma }\end{array}$ & $\begin{array}{l}1 \\
(0.14 \%)\end{array}$ & - & - & & & & \\
\hline Myxoma & $\begin{array}{l}20 \\
(2.86 \%)\end{array}$ & $\begin{array}{l}7 \\
(1.88 \%)\end{array}$ & $\begin{array}{l}3 \\
(1.72 \%)\end{array}$ & $\begin{array}{l}\text { Extrapleural solitary } \\
\text { fibrous tumour }\end{array}$ & $\begin{array}{l}5 \\
(0.71 \%)\end{array}$ & - & - & & & & \\
\hline Nodular fasciitis & $\begin{array}{l}24 \\
(3.43 \%)\end{array}$ & $\begin{array}{l}18 \\
(4.84 \%)\end{array}$ & $\begin{array}{l}12 \\
(6.9 \%)\end{array}$ & Fibrosarcoma & $\begin{array}{l}3 \\
(0.43 \%)\end{array}$ & $\begin{array}{l}3 \\
(0.81 \%)\end{array}$ & $\begin{array}{l}1 \\
(0.57 \%)\end{array}$ & & & & \\
\hline Perineurioma & $\begin{array}{l}1 \\
(0.14 \%)\end{array}$ & - & - & Leyomyosarcoma & $\begin{array}{l}14 \\
(2.0 \%)\end{array}$ & $\begin{array}{l}9 \\
(2.42 \%)\end{array}$ & $\begin{array}{l}5 \\
(2.87 \%)\end{array}$ & & & & \\
\hline Schwannoma & $\begin{array}{l}83 \\
(11.86 \%)\end{array}$ & $\begin{array}{l}54 \\
(14.52 \%)\end{array}$ & $\begin{array}{l}22 \\
(12.64 \%)\end{array}$ & Liposarcoma $^{a}$ & $\begin{array}{l}23 \\
(3.29 \%)\end{array}$ & $\begin{array}{l}4 \\
(1.08 \%)\end{array}$ & $\begin{array}{l}3 \\
(1.72 \%)\end{array}$ & & & & \\
\hline \multirow[t]{9}{*}{$\begin{array}{l}\text { Tenosynovial } \\
\text { giant cell tumor }\end{array}$} & $\begin{array}{l}163 \\
(23.29 \%)\end{array}$ & $\begin{array}{l}99 \\
(26.61 \%)\end{array}$ & $\begin{array}{l}49 \\
(28.16 \%)\end{array}$ & Lymphoma & $7(1.0 \%)$ & $\begin{array}{l}1 \\
(0.27 \%)\end{array}$ & - & & & & \\
\hline & & & & Metastasis & $\begin{array}{l}3 \\
(0.43 \%)\end{array}$ & $\begin{array}{l}1 \\
(0.27 \%)\end{array}$ & - & & & & \\
\hline & & & & $\begin{array}{l}\text { Malignant peripheral } \\
\text { nerve sheath tumor }\end{array}$ & $\begin{array}{l}1 \\
(0.14 \%)\end{array}$ & - & - & & & & \\
\hline & & & & Myofibroblastic tumor & $\begin{array}{l}5 \\
(0.71 \%)\end{array}$ & $\begin{array}{l}4 \\
(1.08 \%)\end{array}$ & $\begin{array}{l}1 \\
(0.57 \%)\end{array}$ & & & & \\
\hline & & & & Myxofibrosarcoma & $\begin{array}{l}19 \\
(2.71 \%)\end{array}$ & $\begin{array}{l}6 \\
(1.61 \%)\end{array}$ & $4(2.3 \%)$ & & & & \\
\hline & & & & Rhabdomyosarcoma & $\begin{array}{l}4 \\
(0.57 \%)\end{array}$ & $\begin{array}{l}1 \\
(0.27 \%)\end{array}$ & - & & & & \\
\hline & & & & Synovial sarcoma & $\begin{array}{l}20 \\
(2.86 \%)\end{array}$ & $\begin{array}{l}9 \\
(2.42 \%)\end{array}$ & $\begin{array}{l}3 \\
(1.72 \%)\end{array}$ & & & & \\
\hline & & & & $\begin{array}{l}\text { Undifferentiated } \\
\text { pleomorphic sarcoma }\end{array}$ & $\begin{array}{l}25 \\
(3.57 \%)\end{array}$ & $\begin{array}{l}8 \\
(2.15 \%)\end{array}$ & $4(2.3 \%)$ & & & & \\
\hline & & & & $\begin{array}{l}\text { Sarcoma, not other } \\
\text { specified }\end{array}$ & $\begin{array}{l}5 \\
(4.29 \%)\end{array}$ & $\begin{array}{l}3 \\
(0.81 \%)\end{array}$ & $\begin{array}{l}1 \\
(0.57 \%)\end{array}$ & & & & \\
\hline
\end{tabular}

of those classified as low-grade liposarcoma/aypical lipomatous tumor: $12 \leq 5 \mathrm{~cm}(1.71 \%), 2 \leq 3 \mathrm{~cm}(0.54 \%), 2 \leq 2 \mathrm{~cm}(1.15 \%)$

rate. STMs located in the head and neck were the only subgroup of lesions which showed a tendency towards an increasing malignancy rate with decreasing tumor diameter.

The malignancy rate was significantly lower in age group $\mathrm{B}$ as compared to age groups $\mathrm{A}$ and $\mathrm{C}$ for lesions $\leq 5 \mathrm{~cm}, \leq 3 \mathrm{~cm}$, and $\leq 2 \mathrm{~cm}(P<0.001, P=0.003$ and $P$ $=0.022)$. Percentages are shown in Table 5 .

\section{Discussion}

In this study, we evaluated the distribution of entities of soft tissue tumors with a maximum diameter of $5 \mathrm{~cm}$ in 


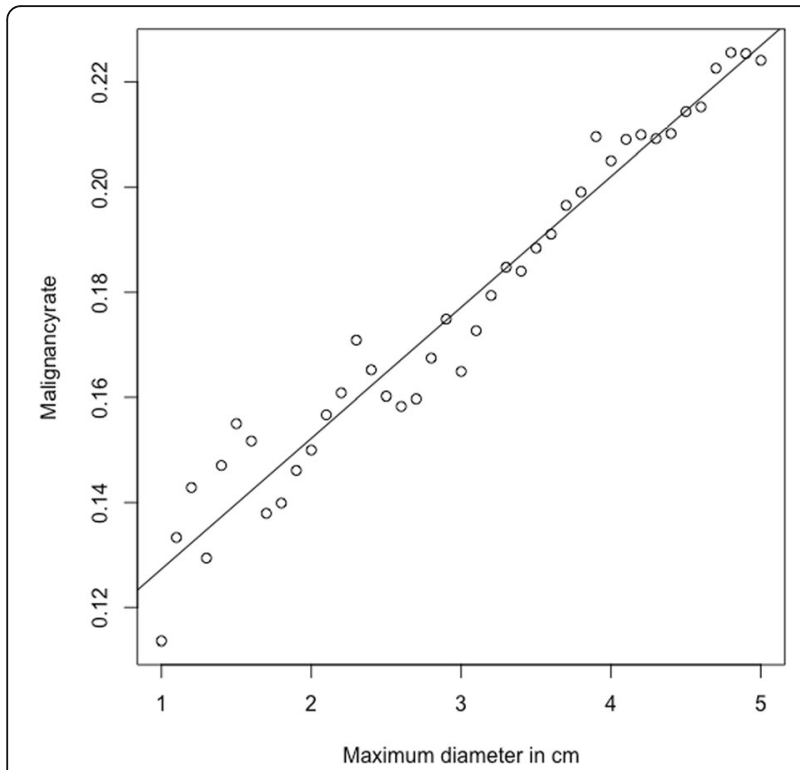

Fig. 1 Regression analysis for malignancy rate as function of maximum diameter

a large series of a tertiary referral center and give an overview of expected entities and likelihood of malignancy of small lesions in initial diagnosis.

The distribution of entities with lipoma and tenosynovial giant cell tumor as most common non-malignant lesions and undifferentiated pleomorphic sarcoma and liposarcoma as most common malignant lesions in general is in line with previous studies [10, 12, 13].

Before this study, in 1995 Kransdorf et al. were the last to give an overview over the distribution of entities of soft tissue masses in a large scale. While Kransdorf et al. included a high number of lesions in their study, lesion size and rates of malignancy for different sizes were not assessed in this previous publication [12].

In this study malignancy rates were analyzed in 870 lesions $\leq 5 \mathrm{~cm}$. Although the malignancy rate of all lesions

Table 4 Malignancy rates of soft tissue masses $\leq 5 \mathrm{~cm}, \leq 3 \mathrm{~cm}$ and $\leq 2 \mathrm{~cm}$ in different locations

\begin{tabular}{llll}
\hline Malignancy rate & $\mathbf{5} \mathbf{~ c m}$ & $\leq \mathbf{3} \mathbf{c m}$ & $\leq \mathbf{2} \mathbf{c m}$ \\
\hline Overall & $22.41 \%$ & $16.49 \%$ & $15.0 \%$ \\
Superficial & $23.53 \%$ & $20.79 \%$ & $18.18 \%$ \\
Deep & $22.14 \%$ & $15.32 \%$ & $13.79 \%$ \\
Head / Neck & $48.57 \%$ & $71.43 \%$ & $80.0 \%$ \\
Trunk & $40,00 \%$ & $33.33 \%$ & $45.45 \%$ \\
Upper Extremity (excluding Hand) & $25.27 \%$ & $24.21 \%$ & $20.45 \%$ \\
Lower Extremity (excluding Foot) & $20.7 \%$ & $11.22 \%$ & $11.11 \%$ \\
Hand & $19.3 \%$ & $19.15 \%$ & $16.67 \%$ \\
Foot & $7.44 \%$ & $5.68 \%$ & $3.70 \%$ \\
\hline
\end{tabular}

Table 5 Malignancy rates of soft tissue masses for age groups A (<18 years), B (18-40 years), and C ( $>40$ years)

\begin{tabular}{llll}
\hline Malignancy rate & $\leq \mathbf{5} \mathbf{~ c m}$ & $\leq \mathbf{3} \mathbf{c m}$ & $\leq \mathbf{2} \mathbf{c m}$ \\
\hline Age group A (<18 years) & $38.89 \%$ & $19.05 \%$ & $23.08 \%$ \\
Age group B (18-40 years) & $12.46 \%$ & $8.07 \%$ & $5.88 \%$ \\
Age group C (> 40 years) & $26.73 \%$ & $20.27 \%$ & $18.31 \%$ \\
\hline
\end{tabular}

$\leq 5 \mathrm{~cm}$ was around $20 \%$ and dropped significantly when assessing lesions $\leq 3 \mathrm{~cm}$ and $\leq 2 \mathrm{~cm}$, still almost every seventh lesion with a diameter of less than $2 \mathrm{~cm}$ was malignant. Decrease of malignancy rate with decrease of lesion diameter is in line with studies published by Chen et al. and Obaid et al. including lesions of all sizes evaluated on MR images $[6,11]$.

When focusing on lesions $\leq 2 \mathrm{~cm}$ a malignancy rate of $15.0 \%$ was observed, whereas Pham et al. published a study focusing on STMs of this size describing a malignancy rate of $21.42 \%$ [10]. The number of lesions assessed in this previous study was however considerably smaller compared to our series $(n=42)$, possibly accounting for the observed variance in malignancy rate. Hsieh et al. also performed an analysis of soft tissue masses, showing significantly lower malignancy rates. In contrast to our study, lesions of all sizes and especially tumors of the skin were included [14]. Overall, the results of our study show that, despite relatively low rates of malignancy, even smaller lesions should be considered as potentially malignant $[6,11]$.

Of 870 lesions $\leq 5 \mathrm{~cm}$ analyzed in our study, the majority was located in the deep soft tissues.

Although the comparison between superficial and deep lesions revealed a different distribution of entities, no significant difference in malignancy rates was observed. These results are in line with those of Datir et al. who also did not observe any influence of lesion depth on malignancy rates comparing STMs of any size on MR imaging [7]. Therefore, the possibility of malignancy of small lesions needs to be considered regardless of the lesion being located superficial or deep to the fascia.

The malignancy rates for patients younger than 18 years and older than 40 years were significantly higher as compared to patients between 18 and 40 years of age. In the group of young patients this was caused by the peak of alveolar soft part sarcoma and synovial sarcoma in adolescence, in patients older than 40 years this was mainly due to the higher percentage of liposarcomas and undifferentiated pleomorphic sarcomas [15].

Furthermore, significant differences of malignancy rates were observed with a view to tumor location in different regions of the body: Lesions of the head and neck showed a relatively high rate of malignancy, whereas soft tissue masses located in the feet showed relatively low malignancy rates. The relatively low malignancy rates in 
the hand and foot might be caused by the high number of tenosynovial giant cell tumors occurring in these regions [16]. Nevertheless, also in these peripheral locations still a considerable number of malignant lesions was found.

Overall, the results of this study show, that independent of the localization of a soft tissue mass it is important to consider even small lesions as potentially malignant. Therefore, both diagnostics and therapy of unclear soft tissue lesions should generally be performed in specialized tumor centers, since ignoring small soft tissue masses or performing primary resection with failure to achieve tumor-free margins can lead to a poor outcome.

Additionally, for physicians initially confronted with patients with small tissue lesions on clinical examination, ultrasound, CT, or MR imaging, this study gives an overview on the distribution of entities depending on size, localization, and depth, and therefore allows an estimation of what can be expected.

This study has limitations. As our institution is a tertiary referral center, there is a selection bias toward malignant lesions with predominantly unclear or likely malignant lesions being referred to our institution and majority of benign lesions being followed up or treated in peripheral institutions. This bias may be enhanced by the fact, that we only investigated lesions that underwent biopsy/resection and thus, had a final histopathological diagnosis. For this reason, the distribution of entities seen in a different clinical setting may differ from the results of this study [17]. Moreover, results may differ from those of other comparable institutions due to different regional and practice-dependent referral patterns $[3,18]$. Finally, no further evaluation of MR characteristics was performed due to the large sample size and the inhomogeneity of MR examinations obtained at different institutions. A narrowing of the differential diagnosis would have likely been possible by analyzing the full MR morphology rather than tumor size and localization only.

\section{Conclusions}

In conclusion, the rate of malignancy decreased significantly with tumor size in both, small superficial and deep STMs. Nevertheless, even small STMs have a considerable likelihood of malignancy and therefore, it is crucial that diagnostics and therapy are performed in specialized institutions. The distribution of entities was different between superficial and deep STMs, yet there was no significant difference found between the two groups regarding the malignancy rate. This study may help to better estimate the distribution of entities and the probability of malignancy of superficial and deep STMs of small size and consequently, to decide whether a biopsy or primary resection should be chosen and to avoid the failure to achieve tumor-free margins.

\section{Abbreviations}

AJCC: American Joint Committee on Cancer; MR: Magnetic resonance; STM: Soft tissue mass; WHO: World Health Organisation

\section{Acknowledgements}

The authors want to thank Mr. Johannes Thurner for the support with the data management.

\section{Authors' contributions \\ FGG assisted with the study design, collected the data, performed the reading of the images, performed the statistical analysis, and drafted the manuscript. FTG collected the data and assisted with data interpretation and manuscript revision. KS, CK and UL assisted with data collection, data interpretation and manuscript revision. MM and RER assisted with manuscript revision. AG contributed to the study design, supervised the reading of the images, assisted with data interpretation and manuscript revision. KW contributed to the study design and data collection, supervised the reading of the images, data interpretation and manuscript revision. All authors substantially contributed to this manuscript and therefore we believe they fulfill the requirements for being listed as authors. They have read and approved the final version of the revised manuscript.}

\section{Funding}

No funding was obtained for this retrospective study. Open Access funding enabled and organized by Projekt DEAL.

\section{Availability of data and materials}

All required data is available within the manuscript.

\section{Ethics approval and consent to participate}

Approval of the Institutional Review Board was obtained prior to this study (Ethikkommitee der Technischen Universität München). Written informed consent was waived for this retrospective analysis of routinely acquired imaging and clinical data.

\section{Consent for publication}

Consent for publication was obtained by all authors prior to submission.

\section{Competing interests}

The authors declare no conflict of interest.

\section{Author details}

${ }^{1}$ Department of Diagnostic and Interventional Radiology, School of Medicine \& Klinikum rechts der Isar, Technical University of Munich, Ismaninger Str. 22, 81675 Munich, Germany. ${ }^{2}$ Department of Pathology, School of Medicine \& Klinikum rechts der Isar, Technical University of Munich, Munich, Germany. ${ }^{3}$ Department of Orthopaedic Surgery, School of Medicine \& Klinikum rechts der Isar, Technical University of Munich, Munich, Germany.

Received: 28 September 2020 Accepted: 25 December 2020 Published online: 22 January 2021

\section{References}

1. Noone AMHN, Krapcho M, Miller D, Brest A, Yu M, Ruhl J, Tatalovich Z, Mariotto A, Lewis DR, Chen HS, Feuer EJ, Cronin KA. SEER Cancer Statistics Review, 1975-2015. Bethesda, https://seer.cancer.gov/csr/1975 2015/, based on November 2017 SEER data submission, posted to the SEER web site, April 2018: National Cancer Institute; 2018.

2. Burningham Z, Hashibe M, Spector L, Schiffman JD. The epidemiology of sarcoma. Clin Sarcoma Res. 2012;2(1):14.

3. Quek RHH, Farid M, Wang E, Asavamongkolkul A, Leung A, Prayogo N, Punyaratabandhu T, Yeoh E-M, Shantakumar S, Manson S, et al. Epidemiology, treatment (tx) patterns and outcomes in Asian soft tissue sarcoma (STS) patients: Results from the Soft Tissue Sarcoma in the Asia Pacific Region (STAR) study. J Clin Oncol. 2015;33(15_suppl):10549.

4. Kallen ME, Hornick JL. The 2020 WHO classification: What's new in soft tissue tumor pathology? Am J Surg Pathol. 2020; Publish Ahead of Print.

5. Amin MB, Greene FL, Edge SB, Compton CC, Gershenwald JE, Brookland RK, Meyer L, Gress DM, Byrd DR, Winchester DP. The eighth edition AJCC Cancer staging manual: continuing to build a bridge from a population- 
based to a more "personalized" approach to cancer staging. CA Cancer J Clin. 2017;67(2):93-9.

6. Chen CK, Wu HT, Chiou HJ, Wei CJ, Yen CH, Chang CY, Chen WM. Differentiating benign and malignant soft tissue masses by magnetic resonance imaging: role of tissue component analysis. J Chin Med Assoc. 2009;72(4):194-201.

7. Datir A, James SL, Ali K, Lee J, Ahmad M, Saifuddin A. MRI of soft-tissue masses: the relationship between lesion size, depth, and diagnosis. Clin Radiol. 2008;63(4):373-8 discussion 379-380.

8. Casali PG, Abecassis N, Aro HT, Bauer S, Biagini R, Bielack S, Bonvalot S, Boukovinas I, Bovee J, Brodowicz T, et al. Soft tissue and visceral sarcomas: ESMO-EURACAN Clinical Practice Guidelines for diagnosis, treatment and follow-up. Ann Oncol. 2018;29(Suppl 4):iv268-9.

9. Pretell-Mazzini J, Barton MD Jr, Conway SA, Temple HT. Unplanned excision of soft-tissue sarcomas: current concepts for management and prognosis. J Bone Joint Surg Am. 2015;97(7):597-603.

10. Pham K, Ezuddin NS, Pretell-Mazzini J, Subhawong TK. Small soft tissue masses indeterminate at imaging: histological diagnoses at a tertiary orthopedic oncology clinic. Skeletal Radiol. 2019;48(10):1555-63.

11. Obaid H, Vassos N, Adams SJ, Bryce R, Donuru A, Sinclair N. Development of a risk assessment model to differentiate malignant and benign musculoskeletal soft-tissue masses on magnetic resonance imaging. J Med Imaging Radiat Oncol. 2020;64(1):9-17.

12. Kransdorf MJ. Malignant soft-tissue tumors in a large referral population: distribution of diagnoses by age, sex, and location. AJR Am J Roentgenol. 1995;164(1):129-34.

13. Ozturk R, Arikan SM, Bulut EK, Kekec AF, Celebi F, Gungor BS. Distribution and evaluation of bone and soft tissue tumors operated in a tertiary care center. Acta Orthop Traumatol Turc. 2019;53(3):189-94.

14. Hsieh CY, Tsai HW, Chang CC, Lin TW, Chang KC, Chen YS. Tumors involving skin, soft tissue and skeletal muscle: benign, primary malignant or metastatic? Asian Pac J Cancer Prev. 2015;16(15):6681-4.

15. van Vliet M, Kliffen M, Krestin GP, van Dijke CF. Soft tissue sarcomas at a glance: clinical, histological, and MR imaging features of malignant extremity soft tissue tumors. Eur Radiol. 2009;19(6):1499-511.

16. Monaghan H, Salter DM, Al-Nafussi A. Giant cell tumour of tendon sheath (localised nodular tenosynovitis): clinicopathological features of 71 cases. J Clin Pathol. 2001;54(5):404-7.

17. Beaman FD, Kransdorf MJ, Andrews TR, Murphey MD, Arcara LK, Keeling JH. Superficial soft-tissue masses: analysis, diagnosis, and differential considerations. Radiographics. 2007;27(2):509-23.

18. Poon E, Quek R. Soft tissue sarcoma in Asia. Chin Clin Oncol. 2018;7(4):46.

\section{Publisher's Note}

Springer Nature remains neutral with regard to jurisdictional claims in published maps and institutional affiliations.

Ready to submit your research? Choose BMC and benefit from:

- fast, convenient online submission

- thorough peer review by experienced researchers in your field

- rapid publication on acceptance

- support for research data, including large and complex data types

- gold Open Access which fosters wider collaboration and increased citations

- maximum visibility for your research: over $100 \mathrm{M}$ website views per year

At $\mathrm{BMC}$, research is always in progress.

Learn more biomedcentral.com/submissions 